\title{
Profesionalisme Pegawai Negeri Sipil Pada Bagian Pengadaan Barang Dan Jasa Sekretariat Daerah Kota Dumai
}

\author{
Dwi Fifi Dasriyanti ${ }^{1 *}$, Zaili Rusli ${ }^{2}$, Harapan Tua Ricky Freddy $\mathbf{S}^{3}$ \\ ${ }^{123}$ Magister Ilmu Administrasi Program Pascasarjana,Universitas Riau \\ Korespondensi :fifi.dwi@gmail.com
}

\begin{abstract}
This study aims to determine the professionalism of civil servants in the Procurement Section of the Dumai City Regional Secretariat and identify the supporting or inhibiting factors. This research is a qualitative research with a case study approach. The data collection technique used was through observation, interviews and documentation with informants consisting of civil servants in the Procurement Section of Goods and Services, PPK/Procurement Officials on Regional Apparatus and providers. Data analysis techniques include data collection, data reduction, data presentation and drawing conclusions. The results of the study indicate that the professionalism of civil servants in the Procurement Section of the Dumai City Regional Secretariat needs to be improved. This can be seen from several aspects. First, competence which shows that there is still a lack of technical capability in the implementation of the procurement of goods and services. Second, effectiveness shows that the process of procuring goods and services has been running according to predetermined standards and times. Third, efficiency shows that the utilization of civil servants and facilities and infrastructure in the Goods and Services Procurement Section is still low in the implementation of the procurement of goods and services. Fourth, responsibilities that show that there are still tupoksi that have not been carried out optimally such as monitoring, evaluating, coaching and advocating related to the process of procurement of goods and services.
\end{abstract}

Keywords: Professionalism, Civil Servants, Procurement of Goods and Services

\begin{abstract}
ABSTRAK
Penelitian ini bertujuan untuk mengetahui profesionalisme pegawai negeri sipil pada Bagian Pengadaan Barang dan Jasa Sekretariat Daerah Kota Dumai serta mengidentifikasi faktor pendukung atau penghambatnya. Penelitian ini merupakan penelitian kualitatif dengan pendekatan studi kasus. Teknik pengumpulan data yang digunakan melalui observasi, wawancara dan dokumentasi dengan informan yang terdiri dari PNS pada Bagian Pengadaan Barang dan Jasa, PPK/Pejabat Pengadaan pada Perangkat Daerah dan pihak penyedia. Teknik analisis data meliputi pengumpulan data, reduksi data, penyajian data dan penarikan kesimpulan. Hasil penelitian menunjukkan bahwa profesionalisme pegawai negeri sipil pada Bagian Pengadaan Barang dan Jasa Sekretariat Daerah Kota Dumai perlu ditingkatkan. Hal tersebut dapat dilihat dari beberapa aspek. Kesatu, kompetensi yang memperlihatkan bahwa masih kurangnya kemampuan teknis pelaksanaan pengadaan barang dan jasa. Kedua, efektivitas menunjukan bahwa proses pengadaan barang dan jasa sudah berjalan sesuai dengan standar dan waktu yang telah ditetapkan sebelumnya. Ketiga, efisiensi memperlihatkan bahwa masih rendahnya pemanfaatan pegawai negeri sipil dan sarana dan prasarana pada Bagian Pengadaan Barang dan Jasa dalam pelaksanaan pengadaan barang dan jasa. Keempat, tanggung jawab yang memperlihatkan bahwa masih terdapat tupoksi yang belum dilaksanakan secara optimal seperti melakukan pemantauan, evaluasi, pembinaan dan advokasi terkait proses pengadaan barang dan jasa.
\end{abstract}

Kata Kunci : Profesionalisme, Pegawai Negeri Sipil, Bagian Pengadaan Barang dan Jasa 


\section{PENDAHULUAN}

Kebutuhan pembangunan pada era otonomi daerah saat ini sangat diperlukan oleh setiap daerah yang akan dilaksanakan oleh pemerintah daerah sebagai institusi yang memiliki fungsi sebagai penyelenggara kegiatan pembangunan dan pelayanan dalam mewujudkan kesejahteraan masyarakat. Salah satu kebutuhan pembangunan yaitu kebutuhan pengadaan barang dan jasa. Tanpa adanya pengadaan barang dan jasa maka pembangunan tidak dapat terlaksana sehingga anggaran pemerintah daerah tidak terserap dan akan mengakibatkan masyarakat tidak bisa menikmati hasil pembangunan. Untuk menjalankanproses pengadaan barang dan jasa tersebut maka Pemerintah Kota Dumai didukung oleh pegawai negeri sipil yang bertugas pada Bagian Pengadaan Barang dan Jasa dibawah pengendalian Asisten Perekonomian dan Pembangunan Sekretariat Daerah.

Berdasarkan Peraturan Walikota Dumai Nomor 14 Tahun 2020 tentang Kedudukan, Susunan Organisasi, Tugas dan Fungsi serta Tata Kerja Sekretariat Daerah Kota Dumai, Bagian Pengadaan Barang dan Jasa memiliki tugas melaksanakan penyiapan perumusan kebijakan daerah, pengoordinasian perumusan kebijakan daerah, pengoordinasian pelaksanaan tugas Perangkat Daerah, pelaksanaan pemantauan dan evaluasi di bidang pengelolaan pengadaan barang dan jasa, pengelolaan layanan pengadaan secara elektronik, pembinaan dan advokasi pengadaan barang dan jasa. Mengingat beban pekerjaan, tanggung jawab serta resiko yang tinggi dalam pelaksanaan tugas tersebut maka sudah sepantasnya pegawai negeri sipil pada Bagian ini dituntut untuk bersikap profesional mulai dari tahap perencanaan hingga proses pengadaan Saputra, T., Eka, E., \& Sufi, W. (2021).

Undang-Undang Nomor 5 Tahun 2014 tentang Aparatur Sipil Negara juga menyebutkan bahwa dalam rangka mewujudkan tujuan negara maka salah satunya diperlukan aparatur sipil negara yang profesional. Profesionalisme pegawai negeri sipil yang merupakan bagian dari aparatur sipil negara juga merupakan tujuan reformasi birokrasi sebagaimana dalamUndang-Undang Nomor 17 Tahun 2007 tentang Rencana Pembangunan Jangka Panjang Nasional 2005-2025 yang mengemukakan bahwa pembangunan aparatur negara dilakukan melalui reformasi birokrasi untuk meningkatkan profesionalisme aparatur negara dan untuk mewujudkan tata pemerintahan yang baik, di pusat maupun di daerah, agar mampu mendukung keberhasilan pembangunan di bidang-bidang lainnya.

Hal ini sejalan dengan misi Kota Dumai yaitu misi ke-4 (empat) "Mewujudkan pemerintahan yang efektif, bersih melalui penyelenggaraan pemerintahan yang profesional, aspiratif, partisipatif dan transparan." Untuk mewujudkan misi tersebut, pegawai negeri sipil sebagai salah satu unsur penting dalam birokrasi pemerintah diharapkan dapat menyesuaikan diri dengan perubahan-perubahan yang terjadi baik dalam tataran internal maupun eksternaldengan memiliki sikap profesionalisme pada saat menjalankan tugas pokok dan fungsinya sehingga pelaksanaan pemerintahan dapat berjalan efektif.

Profesionalisme pegawai negeri sipil pada Bagian Pengadaan Barang dan Jasa Sekretariat Daerah Kota Dumai perlu mendapat perhatian karena berdasarkan pengamatan awal masih ditemui pegawai negeri sipil yang belum memiliki sertifikat ahli pengadaan barang dan jasa, belum mengikuti dan lulus pelatihan fungsional dan teknis terkait tupoksi, belum terpenuhinya syarat jabatan sesuai dengan analisa jabatan dan belum optimalnya penyelesaian tugas sesuai tupoksi yang diberikan.

Profesionalisme dapat diartikan sebagai hasil kerja yang sesuai dengan standar teknis atau etika sebuah profesi seperti yang dikemukakan oleh Imawan dalam Munirah (2020:8). Chaerudin dkk (2020:493) juga berpendapat bahwa dalam pengertian bahasanya, profesionalisme mempunyai beberapa makna yaitu Pertama profesionalisme berarti suatu keahlian, mempunyai kualifikasi tertentu, berpengalaman sesuai dengan bidang keahliannya, Kedua profesionalisme merujuk pada suatu standar pekerjaan yaitu prinsip-prinsip moral dan etika profesi, Ketiga profesional berarti moral".

Konsep profesionalisme menurut Hall (dalam Chaerudin dkk, 2020:494) yaitu,'(1) Hubungan dengan sesama profesi (community affiliation), elemen ini berkaitan dengan pentingnya menggunakan 
ikatan profesi sebagai acuan, termasuk di dalamnya organisasi formal dan kelompok kolega informal sumber ide utama pekerjaan; (2) Kebutuhan untuk mandiri (autonomy demand), yaitu suatu pandangan menyatakan seseorang yang profesional harus mampu membuat keputusan sendiri tanpa adanya tekanan dari pihak lain (pemerintah, klien, atau yang bukan anggota profesi); (3) Keyakinan terhadap peraturan sendiri/profesi (belief self regulation) maksudnya bahwa yang paling berwenang dalam penilaian pekerjaan profesional adalah rekan sesama profesi, bukan 'orang luar' yang tidak mempunyai kompetensi dalam bidang ilmu dan pekerjaan yang sama; (4) Dedikasi pada profesi (dedication), elemen ini merupakan pencerminan dari dedikasi profesional dengan menggunakan pengetahuan dan kecakapan yang dimiliki untuk tetap teguh dalam melaksanakan pekerjaannya meskipun imbalan ekstrinsik yang diterima dikurangi Yuliani, F., Saputra, T., \& Pratami, A. (2020); (5) Kewajiban sosial (social obligation), elemen ini menunjukkan pandangan tentang pentingnya profesi serta manfaat yang didapatkan baik oleh masyarakat maupun profesional karena adanya pekerjaan tersebut".

Demikian juga dengan yang dikatakan oleh Korten dan Alfonso (1981) dalam Tjokrowinoto (2012:178), yang dimaksud profesionalisme adalah kecocokan (fitness) antara kemampuan yang dimiliki birokrasi (bureaucratic-competence) dengan kebutuhan tugas (task-requirement). Terpenuhinya kecocokan antara kemampuan aparatur dengan kebutuhan tugas merupakan syarat terbentuknya aparatur yang profesional. Artinya, keahlian dan kemampuan aparat merefleksikan arah dan tujuan yang ingin dicapai oleh sebuah organisasi. Pandangan lain seperti yang dikemukakan Sedarmayanti (2017:342) menyatakan bahwa,'Profesionalisme adalah pilar yang akan menempatkan birokrasi sebagai mesin yang efektif bagi pemerintah dan sebagai parameter kecakapan aparatur dalam bekerja secara baik. Ukuran profesionalisme adalah kompetensi, efisiensi dan efektivitas serta bertanggung jawab".

1. Kompetensi adalah segala hal pengetahuan, keahlian, kemampuan dan karakteristik lain yang menyebabkan seseorang pemegang suatu jabatan mampu melaksanakan peran dan tanggung jawabnya dan memberikan kontribusi bagi pemenuhan kebutuhan organsasi perusahaan sesuai tingkat jabatan yang dipegangnya dapat diestimasikan bahwa kompetensi yang dibutuhkan agar organsasi dapat survive dalam mengahadapi tantangan dan perubahan masa depan;

2. Efektivitas merupakan suatu ukuran yang memberikan gambaran seberapa jauh target dapat tercapai. Pengertian efektivitas ini lebih berorientasi kepada keluaran sedangkan masalah penggunaan masukan kurang menjadi perhatian utama. Apabila efisiensi dikaitkan dengan efektivitas maka walaupun terjadi peningkatan efektivitas belum tentu efisiensi meningkat;

3. Efisiensi merupakan perbandingan terbaik antara suatu pekerjaan yang dilakukan dengan hasil yang dicapai oleh pekerjaan tersebut sesuai dengan yang ditargetkan baik dalam hal mutu maupun hasilnya yang meliputi pemakaian waktu yang optimal dan kualitas cara kerja yang maksimal;

4. Tanggung jawab merupakan kewajiban seseorang untuk melaksanakan fungsi-fungsi yang ditugaskan dengan sebaik-baiknya sesuai dengan pengarahan yang diterima.

Selain itu, untuk mengembangkan profesionalisme terdapat beberapa hal yang perlu dilakukan sebagaimana yang diungkapkan Dwiyanto (2011:158) yaitu:

1. Profesionalisme membutuhkan aparat birokrasi yang membutuhkan tingkat pendidikan yang tinggi dan pengetahuan yang luas. Birokrasi pemerintah harus berani menetapkan standar minimum pendidikan aparaturnya. Aparatur birokrasi publik di masa depan setidak-tidaknya harus menamatkan program diploma, atau bahkan sarjana. Mereka harus memiliki akses terhadap perkembangan ilmu pengetahuan dan teknologi. Pemerintah harus melakukan infestasi SDM sehingga aparatur birokrasi dapat memiliki kualifikasi pendidikan minimal yang diperlukan untuk menduduki jabatan tertentu dalam birokrasi publik;

2. Membangun aparatur yang profesional memerlukan pelembagaan nilai, sikap, dan perilaku yang diturunkan dari kemajuan ilmu pengetahuan dan teknologi serta didorong keinginan untuk 
mewujudkan kehidupan masyarakat yang lebih baik dan bermartabat. Aparatur birokrasi yang profesional harus berani meninggalkan cara kerja yang tradisional dan rutin serta selalu berusaha menciptakan kebaruan dalam cara menyelenggarakan kegiatan pemerintahan dan pelayanan publik;

3. Untuk mempercepat pengembangan profesionalisme dalam birokrasi, pemerintah juga perlu mendorong dan memfasilitasi pengembangan administrator publik sebagai sebuah profesi yang berdiri sendiri, sebagaimana profesi lainnya. Selama ini administrator publik belum menjadi sebuah profesi yang diakui oleh publik. Apabila administrator publik dapat dijadikan sebuah profesi, keberadaannya tentu akan dapat mempercepat peningkatan profesionalisme dalam birokrasi publik;

4. Profesionalitas aparatur birokrasi dapat dikembangkan ketika mereka memiliki ruang yang memadai untuk mengambil diskresi. Kecenderungan birokrasi pemerintah sekarang ini yang bersifat ruledriven perlu diperbaiki agar aparatur birokrasi memiliki kapasitas untuk merespon dinamika yang terjadi dalam lingkungannya secara kreatif dan responsif.

Surjadi (2012:36) berpendapat bahwa,"Aparatur pemerintah yang profesional adalah aparatur yang memiliki kemampuan pelaksanaan tugas berdasarkan ilmu pengetahuan dan pengalaman dengan mendasarkan kepada etik profesi, mengembangkan kemampuan pengendalian diri (self control) dan berorientasi kepada kualitas kerja dengan cara kerja yang efisien, efektif dan ekonomis memiliki kepekaan (responsiveness) yang tinggi terhadap kepentingan masyarakat (public interest) dan masalahmasalah masyarakat (public affairs) serta melaksanakan kewajiban memberikan pertanggungjawaban (accountability) atas setiap kegiatan yang dilaksanakan".

\section{METODE}

Penelitian yang digunakan adalah penelitian kualitatif dengan pendekatan studi kasus dimana akan dilakukan eksplorasi secara mendalam terhadap program, kejadian, proses, aktifitas, terhadap satu atau lebih orang (Sugiyono, 2020:6). Penelitian dilakukan pada Bagian Pengadaan Barang/Jasa Sekretariat Daerah Kota Dumai dengan informan yang terdiri dari: 1) PNS pada Bagian Pengadaan Barang/Jasa,2) PPK/Pejabat Pengadaan pada Perangkat Daerah dan 3) Pihak Penyedia. Pengumpulan data dilakukan dengan cara observasi, wawancara dan dokumentasi.Kemudian teknik analisis data dalam penelitian ini menggunakan model Miles dan Huberman (Sugiyono, 2020:132) yang mengemukakan bahwa aktifitas dalam analisis data kualitatif dilakukan secara interaktif dan berlangsung secara terus menerus dan sampai tuntas, sehingga datanya sudah jenuh. Langkah-langkah yang dilakukan dalam analisis data ini yaiu data collection (pengumpulan data), data reduction (reduksi data), data display (penyajian data) dan conclusion drawing/verification (penarikan kesimpulan).

\section{HASIL DAN PEMBAHASAN}

Bagian Pengadaan Barang dan Jasa merupakan salah satu bagian di Sekretariat Daerah Kota Dumai di bawah pengendalian Asisten Perekonomian dan Pembangunan yang didukung oleh 10 (sepuluh) personil terdiri dari 4 (empat) orang pejabat struktural, 3 (tiga) orang fungsional tertentu dan 3 (tiga) orang fungsional umum. Profesionalisme pegawai negeri sipil pada penelitian ini akan dianalisis dengan menggunakan teori Sedarmayanti (2017:342) bahwa pengukuran profesionalisme adalah kompetensi, efektivitas dan efisiensi serta bertanggung jawab.

\section{Kompetensi}

Kompetensi pada penelitian merupakan kemampuan pegawai negeri sipil dalam memahami dan melaksanakan proses pengadaan barang dan jasa dimulai dari pemahaman mengenai ketentuan umum 
pengadaan barang dan jasa, perencanaan, persiapan hingga pelaksanaan pengadaan barang dan jasa, yang dilihat dari kemampuan mengatasi berbagai permasalahan proses pengadaan barang dan jasa dengan memberikan solusi sesuai ketentuan yang berlaku, kemampuan menyusun dokumen perencanaan, persiapan hingga melaksanakan proses pengadaan baik secara swakelola maupun melalui penyedia.

Kepala Bagian Pengadaan Barang dan Jasa menyatakan bahwa kemampuan teknis pegawai negeri sipil terkait proses pengadaan barang dan jasa masih rendah dikarenakan kurangnya keikutsertaan pegawai negeri sipil mengikuti diklat teknis, sosialisasi maupun bimbingan teknis.

“...saya akui pegawai disini kurang mengikuti diklat teknis, sosialisasi maupun bimbingan teknis yang sering diadakan LKPP. Jadi terkadang ada beberapa pegawai yang belum menguasai secara teknis proses pengadaan yang dimaksud. Kebijakan terkait pengadaan barang dan jasa ini cepat sekali berubahnya...," ujar Kepala Bagian Pengadaan Barang dan Jasa.

Jawaban serupa juga diberikan oleh Pihak Penyedia yang menyatakan bahwa terdapat pegawai yang kurang mengetahui teknis proses pengadaan barang dan jasa.

".....kemarin saya pernah bertanya langsung ke sana tetapi jawabannya kurang memuaskan. Sepertinya mereka kurang memahami kebijkaan terbaru mengenai proses pengadaan barang dan jasa....., ujar Nora sebagai pihak penyedia.

Berdasarkan wawancara dan observasi, ditemukan bahwa kompetensi pegawai negeri sipil pada Bagian Pengadaan Barang dan Jasa Sekretariat Daerah Kota Dumai belum kompeten. Hal ini terlihat dari hasil wawancara dengan Kepala Bagian Pengadaan Barang dan Jasa dan pihak penyedia bahwa masih terdapat keluhan mengenai penyampaian informasi mengenai pemahaman teknis pegawai dalam proses pengadaan barang dan jasa.

\section{Efektivitas}

Efektivitas pada penelitian ini merupakan tingkat keberhasilan pegawai negeri sipil dalam menyelesaikan proses pengadaan barang dan jasa dengan hasil yang sesuai tujuan dan waktu yang telah ditetapkan sebelumnya yang dapat dilihat dari banyaknya pengadaan barang dan jasa yang terselesaikan sesuai dengan jadwal yang telah ditetapkan serta kualitas atau mutu barang dan jasa yang dihasilkan dari proses pengadaan barang dan jasa sesuai dengan dokumen persyaratan pengadaan barang dan jasa.

Pihak penyedia menyatakan bahwa dalam melakukan proses pengadaan barang dan jasa sudah sesuai dengan jadwal yang telah diumumkan di website: lpsedumaikota.go.id dan sesuai dengan persyaratan yang telah ditetapkan.

“...pengadaan barang dan jasa yang berlangsung sudah sesuai semua baik dari segi waktu maupun prosedur. Kalaupun ada waktu yang tidak sesuai biasanya mereka konfirmasi ulang melalui website...," ujar Yeni sebagai pihak penyedia.

Tidak jauh berbeda dengan pendapat yang lain, pejabat pengadaan pada Dinas Pendidikan dan Kebudayaan Kota Dumai juga menyatakan bahwa pelaksanaan pengadaan barang dan jasa sudah tepat waktu sesuai dengan yang dijadwalkan meskipun terdapat perpanjangan waktu biasanya disebabkan hal yang teknis.

“.....selama ini proses pengadaan barang dan jasa yang berlangsung terselesaikan secara tuntas dan tepat waktu juga sesuai dengan dokumen persyaratan yang telah kami susun....," ujar Ali sebagai pejabat pengadaan.

Dari hasil wawancara dan observasi yang dilakukan, bahwa dari segi kuantitas kerja pegawai negeri sipil pada Bagian Pengadaan Barang/Jasa Sekretariat Daerah Kota Dumai pelaksanaan pengadaan barang dan jasa telah terselesaikan sesuai dengan jadwal yang telah diumumkan. Walaupun terdapat beberapa pekerjaan yang tidak dapat terlaksana dikarenakan adanya kebijakan dari instansi pusat seperti refocusing anggaran dalam penanganan Covid-19 sehingga berdampak tidak terealisasinya target yang 
telah ditetapkan sebelumnya. Sedangkan dalam segi kualitas kerja pegawai negeri sipil yang terlihat dari hasil dan ketelitian dalam melaksanakan tugasnya terlihat sudah sesuai dengan arahan pimpinan dan standard operational procedure yang telah ditetapkan.

\section{Efisiensi}

Efisiensi pada penelitian ini merupakan upaya yang dilakukan oleh pegawai negeri sipil dengan memanfaatkan sumber daya baik sumber daya manusia, anggaran dan prasarana yang tersedia secara optimal sehingga dapat membantu proses pengadaan barang dan jasa secara cepat dan mudah yang dapat dilihat dari pemanfaatan pegawai negeri sipil pada Bagian Pengadaan Barang dana dalam proses percepatan pengadaan barang dan jasa dan pemanfaatan sarana prasarana dalam menunjang proses pengadaan barang dan jasa.

Wawancara dengan Kepala Bagian Pengadaan Barang dan Jasa menyatakan bahwa sarana dan prasarana belum dapat dimanfaatkan secara optimal seperti pemanfaatan website saat ini hanya terbatas untuk memberikan informasi terkait proses pengadaan barang dan jasa.

"....pengembangan website mapun membuat aplikasi untuk percepatan proses pengadaan barang dan jasa yang sudah ada saat ini telah direncanakan tetapi kami masih berkoordinasi dengan Diskominfo terkait masalah ini...," ujar Kepala Bagian Pengadaan Barang dan Jasa.

Pejabat pengadaan barang dan jasa pada BKPSDM Kota Dumai menyatakan bahwa untuk memperoleh informasi diarahkan ke pegawai tertentu sehingga terkadang memerlukan waktu yang agak lama dalam memperoleh jawaban.

“....kalau menanyakan sesuatu diarahkan ke pegawai tertentu. Terkadang pegawai tersebut dihubungi melalui telepon tidak diangkat atau tidak ada di tempat jadi agak memakan waktu aja....," ujar Elfa sebagai pejabat pengadaan.

Berdasarkan hasil wawancara dan observasi, ditemukan bahwa pemanfataan sumber daya yang tersedia seperti sumber daya manusia, anggaran dan prasarana masih belum efisien. Hal ini terlihat dari pemanfatan pegawai negeri sipil pada Bagian Pengadaan Barang dan Jasa dalam memberikan informasi terkait proses pengadaan barang dan jasa diarahkan ke pegawai tertentu saja selain itu pemanfatan teknologi informasi dalam rangka percepatan proses pengadaan barang dan jasa belum dapat berjalan maksimal. Informasi yang diberikan saat ini hanya melalui telepon dan datang langsung ke kantor Bagian Pengadaan Barang dan Jasa.

\section{Tanggung jawab}

Tanggung jawab pada penelitian ini merupakan kesanggupan pegawai negeri dalam melaksanakan pekerjaan yang dibebankan kepadanya dengan sebaik-baiknya dan tepat pada waktunya yang dapat dilihat dari penyelesaian tugas tepat waktu dan sesuai dengan standar operasional prosedur pengadaan barang dan jasa, pemberian layanan yang optimal terkait proses pengadaan barang dan jasa serta sanggup menanggung resiko terhadap permasalahan yang muncul atau keputusan yang diambil.

Menanggapi pertanyaan mengenai tanggung jawab pegawai pada pekerjaan yang diberikan kepadanya, Kepala Bagian Pengadaan Barang dan Jasa berpendapat bahwa sebagian besar bertanggung jawab dalam menyelsaikan pekerjaan masing-masing sesuai dengan tupoksinya. Walaupun terdapat beberapa pekerjaan yang belum tuntas seperti melakukan pemantauan, evaluasi, pembinaan dan advokasi bagi pelaku pengadaan barang dan jasa dikarenakan adanya keterbatasan anggaran.

"....memang ada beberapa tupoksi yang belum tuntas dikerjakan seperti melakukan pemantauan, evaluasi, pembinaan dan advokasi. Saat ini kami baru melakukan pemantauan dan evaluasi untuk perangkat daerah teknis. Sebenarnya kami sudah menganggarkan tetapi dikarenakan adanya refocusing anggaran jadi tidak dapat terlaksana tapi mudah-mudahan anggaran perubahan ini dapat terlaksana karena sedang kami usulkan...," ujar Kepala Bagaian Pengadaan Barang dan Jasa.

Hal ini juga disampaikan oleh informan dari Pejabat Pengadaan BKPSDM Kota Dumai bahwa belum pernah mendapat pembinaan dari Bagian pengadaan Barang dan Jasa terkait proses pengadaan 
barang dan jasa. Informasi diperoleh pelaku pengadaan barang dan jasa jika pelaku pengadaan barang dan jasa menanyakan langsung ke Bagian Pengadaan Barang dan Jasa Sekretariat Daerah Kota Dumai.

“....selama 3 tahun menjadi pejabat pengadaan pengadaan barang dan jasa yang dilakukan di BKPSDM belum pernah dievaluasi secara langsung maupun dilakukan pembinaan dan advokasi....," ujar Elfa sebagai pejabat pengadaan.

Berdasarkan hasil wawancara dan observasi bahwa pegawai negeri sipil pada Bagian Pengadaan Barang/Jasa Sekretariat Daerah Kota Dumai belum cukup baik dalam menyelesaikan pekerjaan yang dibebankan kepadanya hal ini terlihat dari adanya beberapa tugas yang belum dilaksanakan secara tuntas seperti melakukan pemantauan, evaluasi, pembinaan dan advokasi terkait proses pengadaan barang dan jasa. Pemantauan hanya dilakukan ke beberapa perangkat daerah teknis seperti Dinas Pekerjaan Umum dan Penataan Ruang, Dinas Pendidikan dan Kebudayaan, Rumah Sakit Umum Daerah dan Dinas Perumahan Rakyat dan Kawasan Pemukiman selain itu pegawai negeri sipil pada Bagian Pengadaan Barang dan Jasa masih kurang dalam melaksanakan pembinaan bagi para pelaku pengadaan barang dan jasa pemerintah.

\section{KESIMPULAN}

1. Profesionalisme pegawai negeri sipil pada Bagian Pengadaan Barang dan Jasa Sekretariat Daerah Kota Dumai belum profesional. Hal ini dapat dilihat dari temuan penelitian pada indikator: Kompetensi yang memperlihatkan masih kurangnya kemampuan teknis pelaksanaan pengadaan barang dan jasa; Efektivitas menunjukan bahwa proses pengadaan barang dan jasa sudah berjalan sesuai dengan standar dan waktu yang telah ditetapkan sebelumnya; Efisiensi memperlihatkan bahwa masih rendahnya pemanfaatan pegawai negeri sipil dan sarana dan prasarana pada Bagian Pengadaan Barang dan Jasa dalam pelaksanaan pengadaan barang dan jasa; Tanggung jawab yang belum optimal seperti belum melakukan pemantauan, evaluasi, pembinaan dan advokasi terkait proses pengadaan barang dan jasa.

2. Faktor-faktor penghambat profesionalisme pegawai negeri sipil pada Bagian Pengadaan Barang dan Jasa Sekretariat Daerah Kota Dumai antara lain:

1. Tidak adanya kebijakan intenal yang mengatur mengenai petunjuk teknis pengadaan barang dan jasa;

2. Tidak adanya ruang khusus bagi pelayanan konsultasi, pengaduan dan sanggahan baik secara offline maupun online;

3. Kurang akuratnya data realisasi pengadaan barang dan jasa.

\section{SARAN}

Berdasarkan kesimpulan hasil penelitian maka dapat disarankan sebagai berikut:

1. Profesionalisme Pegawai bagian Pengadaan Barang dan Jasa perlu ditingkatkan terutama pada aspek Kompetensi, Efisiensi dan Tanggung jawab. Dalam hal kompetensi diharuskan kepada pegawai negeri sipil mengikuti diklat teknis/ bimbingan teknis terkait pelaksanaan pengadaan barang dan jasa, efisiensi perlu dilakukan pembagian tugas serta koordinasi antar pegawai dan pengembangan aplikasi dalam percepatan proses pengadaan barang dan jasa dan dalam hal tanggung jawab perlu diberlakukan reward and punishment bagi pegawai yang tidak melaksanakan tupoksinya.

2. Agar Kepala Bagian Pengadaan Barang dan Jasa Sekretariat Daerah Kota Dumai: a.membuat 
kebijakan internal yang mengatur mengenai petunjuk teknis pengadaan barang dan jasa; b.membuat ruang khusus untuk layanan konsultasi, pengaduan dan sanggahan secara offline dan membuat aplikasi berbasis teknologi informasi secara online yang dapat diakses secara cepat dan mudah; c.melaksanakan fungsi koordinasi dan monitoring ke perangkat daerah secara aktif dan membuat aplikasi yang dapat terintegrasi agar data realisasi pengadaan barang dan jasa akurat.

\section{DAFTAR PUSTAKA}

[1] Chaerudin. dkk. 2020. Sumber Daya Manusia: Pilar Utama Kegiatan Operasional Organisasi. Jejak. Sukabumi

[2] Dwiyanto. Agus. 2011. Mengembalikan Kepercayaan Publik Melalui Reformasi Birokrasi. Gramedia Pustaka Utama. Jakarta

[3] Munirah. 2020. Menjadi Guru Beretika dan Profesional. Insan Cendekia Mandiri. Solok

[4] Sedarmayanti. 2017. Manajemen Sumber Daya Manusia Reformasi Birokrasi dan Manajemen Pegawai Negeri Sipil. Edisi Revisi. Refika Aditama. Bandung

[5] Sugiyono. 2020. Metode Penelitian Kualitatif. Alfabeta. Bandung

[6] Surjadi. 2012. Pengembangan Kinerja Pelayanan Publik. Refika Aditama. Bandung

[7] Saputra, T., Eka, E., \& Sufi, W. (2021). Preparation of the 2020-2024 Riau Provincial Government Bureaucratic Reform Planning. Warta Pengabdian, 15(2), 82-97. doi:10.19184/wrtp.v15i2.21979

[8] Tjokrowinoto. Moeljarto. 2012. Pembangunan Dilema dan Tantangan. Pustaka Pelajar. Yogyakarta

[9] Yuliani, F., Saputra, T., \& Pratami, A. (2020). The Influence Of Human Resource Practices On Corporate Environmental Citizenship. Polish Journal of Management Studies, 22(2), 576. 